VERTICAL EXTERNALITIES IN TAX SETTING: EVIDENCE FROM GASOLINE AND CIGARETTES

Timothy J. Besley

Harvey S. Rosen

Working Paper 6517 


\section{VERTICAL EXTERNALITIES IN TAX SETTING: EVIDENCE FROM GASOLINE AND CIGARETTES}

Timothy J. Besley

Harvey S. Rosen

Working Paper 6517

http://www.nber.org/papers/w6517

\section{NATIONAL BUREAU OF ECONOMIC RESEARCH 1050 Massachusetts Avenue Cambridge, MA 02138 April 1998}

We are grateful to Norman Thurston and Andrew Clarkson for excellent research assistance. We are grateful for financial support to the National Bureau of Economic Research and to Princeton's Center for Economic Policy Studies. We have received useful comments from participants at the Conference on Local Public Finance in Asgardstrand, Norway in June 1996, from seminars at the IFS and Rutgers University, and from two referees. Any opinions expressed are those of the authors and not those of the National Bureau of Economic Research.

(C) 1998 by Timothy J. Besley and Harvey S. Rosen. All rights reserved. Short sections of text, not to exceed two paragraphs, may be quoted without explicit permission provided that full credit, including $\mathbb{C}$ notice, is given to the source. 
Vertical Externalities in Tax Setting: Evidence

from Gasoline and Cigarettes

Timothy J. Besley and Harvey S. Rosen

NBER Working Paper No. 6517

April 1998

JEL Nos. H20, H77

\section{ABSTRACT}

A common feature of federal systems is that tax bases are joint property. Consequently, state and federal tax setting decisions are interdependent. Our aim here is to put forward a rudimentary theoretical analysis of this phenomenon, and to use the theory as a framework for econometrically estimating the magnitude of the responses. We find that when the federal government increases taxes, there is a significant positive response of state taxes. For example, a 10-cent per gallon increase in the federal tax rate on gasoline leads to a 3.2-cent increase in the state tax rate.

Timothy J. Besley

Department of Economics

London School of Economics

Houghton Street

London WC2A 2AE

UNITED KINGDOM

and NBER

t.besley@lse.ac.uk
Harvey S. Rosen

Department of Economics

Princeton University

Princeton, NJ 08544-1021

and NBER

HSR@PRINCETON.EDU 


\section{Introduction}

In the United States, a number of consumption tax variants are under consideration, including national retail sales and value-added taxes. State officials have viewed this development with some alarm, noting that the states rely very heavily on sales and excise taxes (about half of state tax revenues). The state governments are not eager to have Washington encroaching on this tax base. How might the states respond to such encroachment? The answer to this question is needed to determine how increases in federal indirect taxes would affect the division of taxing power between Washington and the states. Further, knowing the states' response to changes in federal tax structure is required for assessing the distributional and efficiency implications of such changes.

Similar issues arise in the context of the European Union's current discussions about whether Brussels should be given direct taxing power and, if so, what form this should take. If Brussels is assigned rights to tax bases that member nations also have, then a proper assessment of the overall impact should take effects on tax setting decisions by these nations into account.

Both the U.S. and European situations focus our attention on the fact that an important feature of federal systems is that tax bases are the common property of different tiers of government. In the U.S., for example, both state and federal taxes are levied on labor income, gasoline, and cigarettes, among other things. In such cases, tax setting decisions at different tiers of government are likely to be interdependent and it may no longer make sense to analyze the taxation decisions at one level of government in isolation. It is interesting to compare this situation to the standard model of multi-jurisdictional tax competition, which emphasizes the consequences of externalities between tax setting agencies when factors of production and/or consumers are mobile. This distorts tax setting so that immobile factors and consumers are taxed too highly relative to those that are mobile. There are consequent gains from tax coordination. (See Oates and Schwab [1988].) In contrast, the case studied here involves externalities that occur if jurisdictions overlap in their tax setting powers. As is standard in common resource situations, this would lead us to expect excessive taxation of such goods if one authority fails to internalize the cost of its tax setting decision on others. Again, coordinated action would be needed to avert welfare losses (Dahlby [1995]).

Are such vertical externalities important from a practical standpoint? Existing empirical analyses of proposals to expand federal indirect taxation assume 
simply that the states do not change their tax rates at all. (See, for example, the careful studies of Fullerton and Rogers [1993] and Feenberg, Mitrusi, and Poterba $[1997].)^{1}$ We are not aware of any previous attempts to examine these issues empirically and the theoretical literature is also very thin.

This paper provides a framework for thinking about interdependent tax setting, and uses it to study cigarette and gasoline taxes in the U.S. We produce estimates of the effect of changes in federal excise tax rates upon state taxing decisions, focusing on the impact of the significant increases in the federal tax rates on gasoline and cigarettes that were implemented in 1983.

The remainder of the paper is organized as follows. Section 2 provides a theoretical framework for our analysis. In Section 3 we discuss our data and results. We assemble data on real state gasoline and cigarette tax rates during the period 1975-1989, as well as the federal tax rates on these commodities. Our analysis of this panel data set suggests that when the federal government increases taxes, there is a significant positive response of state taxes. For example, a 10-cent per pack increase in the federal tax rate on cigarettes leads to a 2.7-cent increase in the state tax rate. Section 4 concludes with a summary and suggestions for future research.

\section{Conceptual Background}

This section sets out a simple theoretical structure to represent the relationship between federal and state tax-setting behavior. The basic insight is quite simple-as long as the elasticities of the taxed commodities are not zero, the assumption that states do not respond to federal tax rates is inconsistent with balanced budgeting for all parties, and hence cannot be an equilibrium. We then develop an empirical framework to test the model.

\subsection{Theoretical Framework}

Consider a state government whose objective function depends upon the posttax prices of $N$ goods, denoted $W^{s}\left(q_{1 s}, \ldots, q_{N s}\right)$ where $q_{j s}=p_{j s}+t_{j s}+T_{j}, t_{j s}$ is the state government's tax on good $j$ in state $s$ and $T_{j}$ is the federal government's tax. This objective could be politically motivated as in Hettich and Winer

\footnotetext{
${ }^{1}$ This is also the implicit assumption in policy analyses. See, for example, Joint Committee on Taxation [1996].
} 
[1988] or Dixit [1996], or determined by a benevolent planner as in an optimal tax model. It is not necessary to be specific. The aggregate quantities of each good consumed in state $s$ are given by the vector $X_{s}=\left(X_{1 s}, \ldots, X_{N s}\right)$. The simplest theoretical model supposes that there is a revenue requirement in state $s$ such that $\sum_{j=1}^{N} t_{j s} X_{j s} \geq R_{s}$. A stylized characterization of tax setting supposes that the state government sets taxes to maximize its objective function subject to meeting its revenue requirement, taking federal taxes as given. ${ }^{2}$

We are principally interested in characterizing the reaction of state governments to federal government policy (the shape of their reaction function). We view the federal government as a Stackelberg leader (due to its relative size) whose tax policy changes for reasons exogenous to the model, which is quite plausible in our situation. We are then interested in the comparative static properties of the tax vector $t_{s}=\left(t_{1 s}, \ldots, t_{N s}\right)$ in state $s$ with respect to the federal tax rates $T_{j}$. In principal, there are two kinds of effects. The "own" tax effect $\left(\partial t_{j s} / \partial T_{j}\right)$ gives the effect of an increase in the federal tax on good $j$ on the state tax on good $j$. There are also possible "cross" effects $\left(\partial t_{k s} / \partial T_{j}\right)$ which give effects of a federal tax increase on good $j$ on the states' decision on how to tax good $k \neq j$ at the state level.

Except for some special cases, this kind of comparative static analysis does not yield very tractable or transparent results. Hence, we will content ourselves with describing the main effects intuitively in order to motivate the empirical analysis. There are four main effects to consider:

I. Revenue effect. Federal tax rates affect the amount of revenue that the state government enjoys from a given set of taxes. An increase in federal taxes on goods that are also taxed by the state implies that the states have to raise their rates in order to maintain their revenues.

This is easily illustrated for the case of a single taxed good denoted by $j$. Assume that the pre-tax producer price $p_{j s}$ is fixed and the demand for good $j$ can be written $X_{j s}\left(p_{j s}+t_{j s}+T_{j}\right)$. Then the state tax rate will solve $t_{j s} X_{j s}\left(p_{j s}+\right.$

\footnotetext{
${ }^{2}$ Our approach is similar to that taken by Boadway and Keen [1994], who analyze a model in which a federal and state governments interact in setting taxes and spending on public goods. However, they assume that the government taxes only a single commodity. There has also been some work on federal-state government interactions in other policy contexts. Hamermesh and Scoones [1996] discuss how changes in parameters of the federal unemployment insurance system affect the design of state systems.
} 
$\left.t_{j s}+T_{j}\right)=R_{s}{ }^{3}$ Using this relationship, we can determine the response of the state tax to a change in the federal rate by differentiating to yield:

$$
\frac{d t_{j s}}{d T_{j}}=-\frac{t_{j s} X_{j s}^{\prime}\left(p_{j s}+t_{j s}+T_{j}\right)}{X_{j s}+t_{j s} X_{j s}^{\prime}\left(p_{j s}+t_{j s}+T_{j}\right)} .
$$

Given that $t_{j s}$ is the lowest tax rate consistent with the revenue requirement, the denominator of this expression is positive and hence the whole expression is positive. This is the revenue effect in its simplest guise. If the federal government raises its taxes, thereby discouraging consumption of the good, then the state government is no longer able to meet its revenue requirement. Hence, the state government has to raise its rate. For future reference, the reader can note that, in a multi-tax setting, we would not expect the effect of an increase in good $j$ to affect only the tax on good $j$, but to lead to tax increases across the board.

II. Deadweight loss effect: A second effect arises because the marginal disutility of the tax on a commodity increases with its rate, ceteris paribus. As suggested earlier, this effect arises in the context of several different models of tax setting. Here it is most convenient to think of the issue in terms of a simple optimal tax model, in which governments weigh the marginal deadweight cost associated with the use of different taxes against redistributive benefits. This defines a desired ratio of the state tax on a particular good to its post-tax price-the ad valorem tax rate $t_{j s} / q_{j s}$. An increase in the federal tax rate on good $j$ increases the denominator in the latter expression and thus tends to necessitate an increase in the state tax rate to restore the desired ratio. Hence, like the revenue effect, this deadweight loss effect leads the state government to increase its tax rate.

To illustrate this in a specific context, consider an example where the government cares only about the indirect utility of a representative citizen, demands are independent, there are no income effects, and there is a constant elasticity of demand $\varepsilon_{j s}$ for commodity $j$ in state $s$. We then get the familiar inverse elasticity formula for tax setting:

$$
\frac{t_{j s}}{p_{j s}+t_{j s}+T_{j s}}=\left(\frac{\mu_{s}-1}{\mu_{s}}\right) \frac{1}{\varepsilon_{j s}}(j=1,2, . ., N),
$$

where $\mu_{s}$ is the shadow price of government revenue, i.e. the Lagrange multiplier on the government revenue constraint. The revenue effect discussed above can be

\footnotetext{
${ }^{3}$ We assume that such a value of $t_{j s}$ exists and that if there are multiple solutions to this equation, then the lowest tax consistent with raising the required revenue is chosen.
} 
controlled for in the analysis by considering the comparative static result assuming that $\mu_{s}$ remains fixed. ${ }^{4}$ In this case, it is straightforward to show that an increase in $T_{j}$ (holding $\mu_{s}$ fixed) results in an increase in $t_{j s}$ to maintain the desired ad valorem rate on good $j$.

III. Tax substitutability and complementarity effects: With non-separabilities in demands, we would expect some taxes to be complements with one another and others to be substitutes. This would lead to a more complex and ambiguous set of responses of federal tax changes on state tax setting.

IV. Expenditure effects: We have so far ignored public spending decisions by assuming a fixed revenue requirement. However, it is possible to respond to the reduced revenues when the federal government increases its tax take by reducing public spending. Boadway and Keen [1994] have considered a model of state tax setting, where expenditures on public goods endogenously determine a revenue requirement, but there is only one taxed good. In this model, having the extra margin of reducing expenditure on public goods also renders ambiguous the state response to federal tax policy.

To summarize, then, there are a number of possible influences on the shape of the reaction function. Two of these - the revenue effect and deadweight loss effect - point in favor of a positive slope. However, there are sufficient ambiguities in the theory's predictions to make the analysis less than clear-cut - both the magnitude and direction of the response can only be determined empirically.

\subsection{Empirical Framework}

Our main empirical goal is to estimate the reaction function relating state to federal taxes. In principal, we should allow the whole vector of federal taxes to enter the reaction function for each good. However, this is not possible in our analysis because of severe multicollinearity between the federal tax rates on cigarettes and gasoline. This is due to the fact that the main source of variation in both is a sizable increase that was enacted in 1983. (See Section 3.1 below.) Hence, most of our empirical specifications allow only for "own" tax effects. That is, the equation for the state cigarette tax rate includes the federal cigarette tax

\footnotetext{
${ }^{4}$ This is not quite the same as keeping government revenue constant. However, it is a simple and clean way to isolate this second effect.
} 
rate but not the federal tax rate on gasoline. Similarly, the equation for the state gasoline tax rate includes the federal gasoline tax rate but not the cigarette rate.

Of course, from an empirical viewpoint, in order to isolate the independent impact of the federal tax rate, one must also take into account other variables that might affect the state tax rate. In any given year, the state's tax rate on a commodity depends on several types of variables:

- Macroeconomic variables. Changes in the macroeconomic situation can affect all aspects of state fiscal policy, including commodity tax rates. In our empirical model, we characterize the macroeconomic environment with the national unemployment rate and real gross domestic product.

- State economic and demographic variables. Numerous studies have shown that a state's taxation and spending decisions are influenced by its economic and demographic environment. (See, for example, Craig and Inman [1986].) We use the following economic and demographic variables: population, per capita income, state unemployment rate, proportion of the population between 5 and 17, and proportion of the population over 65 .

- State political variables. As Holtz-Eakin [1988], Besley and Case [1995] and others have shown, a state's political structure also influences fiscal outcomes. To characterize the state's political environment, we include the political party of it's governor, and the proportions of the state house and senate controlled by the Democrats. As discussed below, we also include several variables to measure the political strength of the industries subject to tax.

- Federal fiscal variables. So far, we have assumed that the only federal fiscal variables that affect a state's commodity tax structure are federal commodity tax rates. However, other dimensions of federal policy might have effects as well. In particular, federal grants-in-aid have been shown to influence a wide variety of state fiscal decisions. (See, for example, Hines and Thaler [1995].) We also try to take into account the federal income tax burden on the state, which we compute as the ratio of total federal income taxes collected from the state to state aggregate adjusted gross income.

- State fixed effects. There are certain unchanging characteristics of a state that are likely to impact its fiscal system, for example, climate and geogra- 
phy. To account for these characteristics, we include a dichotomous variable for each state.

To summarize, then, our basic estimating equation takes the form:

$$
t_{j s t}=\alpha_{s}+\beta T_{j t}+\gamma X_{t}+\delta Z_{j s t}+\epsilon_{j s t}
$$

where $t_{j s t}$ is the specific rate of sales taxation on commodity $j$ in each state in each year, $\alpha_{s}$ is a state fixed effect, $T_{j t}$ is the federal sales tax rate in year $t, X_{t}$ is a vector of time-varying regressors common to all states, $Z_{j s t}$ is a vector of timeand state-varying regressors, and $\epsilon_{j s t}$ is a random error term. ${ }^{5}$ Moulton [1986] and others have argued that estimation of an equation like (2.1) by ordinary least squares is likely to lead to downward bias in the standard errors as the coefficients of the "aggregate variables" - the variables which, in our model, do not have an $s$ subscript. To deal with this problem, we use a variant of White's [1980] robust standard error procedure. This allows for common shocks among groups of observations, in this instance observations from the same year. ${ }^{6}$

\section{Data and Results}

\subsection{Data}

Tax Rates. As noted above, our main focus is on the relationship between federal cigarette and gasoline tax rates and their state counterparts. We used annual data on the continental states for the years 1975 to 1989 , inclusive. We begin by discussing the sources and construction of the various tax rates.

From 1975 to January 1, 1983, the federal cigarette tax rate was eight cents per pack. It increased to 16 cents per pack on January 1, 1983. With respect to gasoline taxes, prior to April 1, 1983, the federal gasoline tax was four cents per gallon. It then increased to nine cents per gallon. Also, from January 1 , 1987 to September 1, 1990, a special 0.1-cent tax dedicated to the Underground Storage Tank Leakage Fund was in effect. Since unit taxes (for both cigarettes

\footnotetext{
${ }^{5}$ Equation (2.1) is a reduced form model. Consequently, its parameters embody the coefficients of some structural model that includes a spending equation.

${ }^{6}$ We implement this procedure by producing robust standard errors in Stata specifying year as the "cluster" variable. The Stata manual provides details and a comparison between this and random effects estimators.
} 
and gasoline) are nominal amounts of money, we divided them by the CPI to convert them into real terms. ${ }^{7}$

Taxes on cigarettes and gasoline vary considerably across states. In 1989, for example, the tax per pack on cigarettes ranged from 2 cents in North Carolina to 36.5 cents in Connecticut. In the same year, the tax per gallon on gasoline ranged from 4 cents in Florida to 20.825 cents in Wisconsin. In 1988, motor fuel taxes comprised 6.5 percent of state tax revenues, and taxes on tobacco products comprised 1.8 percent (U.S. Bureau of the Census [1991, p.280]).

An important complication in the computation of the state tax rates is that, in some states, cigarettes and gasoline are subject to ad valorem general sales taxes as well as unit taxes. In 1989, for example, 34 states subjected cigarettes to general sales as well as unit taxes; five states did the same for gasoline. ${ }^{8}$ One can compute a "total" real unit tax rate by taking the unit tax-equivalent of the general sales tax (calculated by multiplying the general sales tax rate by the price), adding this to the statutory unit tax rate, and then dividing by the CPI to adjust for inflation. However, it is not clear whether the tax burden inclusive or exclusive of the general sales tax component is more appropriate in our context. When setting unit taxes on cigarettes and gasoline, do state decision-makers take into account the general sales taxes levied on these commodities? We are not sure of the answer, and therefore estimate our model using tax rates both inclusive and exclusive of the general sales tax. As shown below, our substantive results are not sensitive to the difference.

The state general sales tax rate is also of interest. Hence, we also estimate a model in which the state's general sales tax rate is the left-hand-side variable. The means and standard deviations of the various tax rates are reported at the top of Table 1 .

Other variables. The right-hand-side variables, with their definitions, means,

\footnotetext{
${ }^{7}$ One could argue that because states set statutory rates, the analysis should be conducted in terms of norminal rates. On the other hand, to leave a statutory rate unchanged in the face of a rising price level is, in effect, equivalent to lowering it. While the use of real rates strikes us as being preferable, we re-did the analysis using nominal rather than real rates. In general, the qualitative results that we report below still held - increases in the federal rate led to increases in the corresponding state tax rates. However, the nominal rates did not fit the data as well as the real rates in the sense that they had larger standard errors.

${ }^{8}$ In the case of gasoline, some states use the price before imposition of the unit tax as the base for the ad valorem tax, and some use the price after imposition of the unit tax. For cigarettes, states always apply the ad valorem tax to the post-unit tax price.
} 
and standard deviations, are also reported in Table 1. The national unemployment rate, $U_{f e d, t}$ and real $\mathrm{GDP}_{t}$ comprise the $X_{t}$ vector of Equation (2.1). They are meant to control for the condition of the macroeconomic environment. Next are a set of time-varying variables characterizing the state's economic and demographic situation: state population $\left(P O P_{j t}\right)$, population density $\left(D E N S I T Y_{j t}\right)$, state income $\left(I N C_{j t}\right)$, state unemployment rate $\left(U_{\text {state, } j t}\right)$, the proportion of individuals in the state who are between 5 and $17\left(C H I L D_{j t}\right)$, and the proportion who are over $65\left(A G E D_{j t}\right)$. The state's political environment can also affect fiscal outcomes; previous research has shown that an indicator variable that equals one if the governor is a Democrat $\left(D E M G O V_{j t}\right)$, and the proportions of Democrats in the state Senate and House ( $D E M S E N_{j t}$ and $D E M H O U_{j t}$, respectively), are sensible to include. (See Besley and Case [1995].) In the context of political power and given our focus on cigarettes and gasoline, it makes sense to investigate whether the importance of these industries affects the tax rate on their respective commodities. As rough measures of importance to the state economy, we include $T O B I N C_{j t}$ (tobacco production per dollar of state income) and $G A S I N C_{j t}$ (gasoline production per dollar of state income). As noted above, any unchanging characteristics of the states are accounted for by fixed effects.

Finally, as also noted earlier, characteristics of federal fiscal policy other than commodity tax rates may affect state commodity tax rates. We focus on federal grants to the states $\left(G R A N T S_{j t}\right)$, and the federal income tax burden in the state, $T_{I N C, j t}$, defined as the ratio of the state's federal income tax liability to its adjusted gross income.

\subsection{Results}

Our basic findings are reported in Table 2. Columns (1) and (2) show the results for cigarette and gasoline tax rates (measured exclusive of the general sales tax), respectively. As the estimated coefficients on $T_{C}$ and $T_{G}$ indicate, states do respond when the federal government encroaches on their tax bases. Specifically, from column (1), a 10-cent increase in the real federal unit tax on cigarettes leads to a 2.8-cent increase in the real state cigarette unit tax. From column (2), a 10-cent increase in the real federal tax rate on gasoline induces a 4.1-cent increase in the real state gasoline tax rate. ${ }^{9}$

\footnotetext{
${ }^{9}$ The implied effect of these rate changes upon tax revenues depends on the elasticity of demand for the relevant commodity, inter alia. In general, if demand is inelastic and the state
} 
We note in passing some other interesting results from columns (1) and (2). States with relatively important tobacco industries (as measured by TOBINC) tend to have lower tax rates on tobacco and higher tax rates on gasoline, ceteris paribus, although the coefficients are not significant at conventional levels. Similarly, states with relatively important gasoline industries (as measured by $G A S I N C$ ) tend to have lower gasoline tax rates and higher tobacco rates (although the positive coefficient on GASINC in column (3) is not significant). The signs on these variables are consistent with a lobbying model of tax setting along the lines developed in Dixit [1996].

States with a relatively high proportion of children in their population tend to have higher taxes on cigarettes and gasoline. This may reflect the need for revenues to finance greater levels of education. We also note that generally, when the dichotomous variables for political affiliation are statistically significant, they indicate that tax rates are higher under Democratic control. This is consistent with earlier findings that states with Democratic governments tend to have higher expenditures and taxes, ceteris paribus. (See, e.g., Besley and Case [1995].)

As indicated in Section 3.1 above, a possible problem with the results in columns (1) and (2) is that they do not take into account the general sales taxes that some states levy on cigarettes and tobacco. The relevant decision variable may be the tax inclusive of the general sales tax. Therefore, we re-estimated equation (2.1) with the inclusive tax rates on the left-hand side. The results are reported in columns (3) and (4) of Table 2 . As can be seen by comparing the coefficients on $T_{C}$ and $T_{G}$ to their counterparts in columns (1) and (2), the substantive results are essentially unchanged.

Our theoretical discussion suggested that the revenue effect of an increase in the federal tax rate could account for the positive responses that we have found so far. If the revenue effect is driving the results then we would expect to find a similar impact on other taxes, such as the general sales tax. To investigate this possibility, we estimate a variant of equation (2.1) in which the left-handside variable is $t_{g e n}$, the state general sales tax rate. Collinearity problems again preclude us from examining the impact of the federal cigarette and gasoline taxes simultaneously. In column (5) of Table 2 we examine the effect of the federal cigarette tax rate $\left(T_{C}\right)$; similar results are obtained when we use the gasoline tax rate.

tax is a fairly small fraction of the consumer price, then a positive coefficient on the federal rate can lead to an increase in tax revenues. 
The coefficient on $T_{C}$ is positive and statistically significant-an increase in the federal tax rate on cigarettes induces the states to increase their general sales tax rates. But quantitatively, the impact is very small. A 10-cent increase in the federal tax on cigarettes leads to an increase in the general sales tax of only about 0.26 percentage points. This is consistent, however, with the revenue effect of a federal tax increase being a factor behind the positive responses in columns (1) through (4).

One issue that we have not yet discussed is dynamics. Our model assumes that states adjust to changes in federal tax rates in the year in which these changes are effected. A year is certainly a sufficiently long time period that such contemporaneous adjustment is plausible. Nevertheless, it is also possible that the states react with a lag. ${ }^{10}$ The real federal tax rates on cigarettes and gasoline move too sluggishly to do anything very complicated with respect to dynamics. We therefore did a very simple experiment-we re-estimated the specifications in Table 2 using the lagged rather than the contemporaneous values of $T_{C}$ and $T_{G}$. In all cases, the coefficients on the lagged variables were essentially unchanged from their counterparts in Table 2 , as were the adjusted $R$-squareds for the equations. Thus, while we are not able to say very much about just how long it takes states to respond to changes in the federal tax rates, a response does occur. ${ }^{11}$

Another potentially important problem is that the results in Table 2 may be a

\footnotetext{
${ }^{10}$ Alternatively, the error terms for a given state might be serially correlated. When we estimated our canonical equations allowing for first-order autocorrelation, the coefficients on the federal tax rates continued to be positive and significant. In general, they were smaller in magnitude than the corresponding coefficients in Table 2, but by no more than 1.4 standard errors. When we added a time trend to this specification, it was not statistically significant in any of the equations.

${ }^{11}$ However, in this context it is interesting to note that the proportion of states that raised their nominal tax rates on cigarettes and gasoline in 1983 was greater than in either 1982 or 1984. In 1983, 64.6 percent of the states raised their gasoline rates. The figures for 1982 and 1984 were 56.3 percent and 54.2 percent respectively. Similarly in $1983,72.9$ percent of the states increased their cigarette tax rates. The figures for 1982 and 1984 were 58.3 percent and 45.8 percent respectively. An additional exercise in this spirit is to view the 1983 federal tax increase as an "event", and perform a simple events study approach. We re-estimated our equations replacing the various federal tax rates with a dichotomous variable that took the value of one after 1983 and zero before. For both cigarettes and gasoline, the coefficients were positive and significant. Further, the quantitative magnitudes were consistent with coefficients on the tax variables reported in Table 2 . We also applied the events study to the nominal rates. Here, the coefficient in the cigarettes equation was positive and significant, while the coefficient for gasoline was positive but insignificant.
} 
consequence of a spurious correlation between state and federal excise tax rates. For example, new information on the health effects of tobacco might become available to all governments at the same time, inducing them to increase taxes on cigarettes simultaneously. Alternatively, both federal and state gasoline tax rates might react to changes in the world price of oil at the same time and in the same way, or changes in state tax rates might feed back to affect federal tax rates. Whatever the story, the econometric implication is that there may be a correlation between the federal tax rate and the error term. The natural way to deal with this problem is to find an instrument that is correlated with the federal tax rate and uncorrelated with the regression error. For these purposes we select the federal deficit as a percentage of GDP. The instrumental variable results are reported in Table 3 . Compared to their ordinary least squares counterparts in Table 2, the coefficients on the federal tax rate variables are a bit smaller, as are the implied t-statistics. But the substantive result is unchanged-when the federal tax rate on a commodity increases, then so does the state rate, ceteris paribus.

\section{Conclusion}

In the U.S. fiscal system, the federal government and the states share access to some of the same tax bases. When the federal government changes the rate that it applies to these bases, standard theoretical considerations suggest that the states will change their rates in response. This paper documents that, in the cases of gasoline and cigarettes, when the federal government increases its tax rates, the states respond by substantially increasing theirs. To the extent these results generalize, one would expect to see profound effects upon state public finance if the federal government were to move in the direction of greater reliance upon consumption-based taxes.

Also of interest in our empirical results is the importance of variables reflecting political economy concerns. The political complexion of legislative and gubernatorial control are one aspect of this phenomenon. The fact that states with higher outputs of gasoline and cigarettes have lower taxes on these goods may also be indicative of the power of producer lobbies.

These results suggest at least two directions for future research. First, it would be useful to estimate how conventional analyses of the distributional and efficiency consequences of federal excise taxes change when the effects upon state tax rates are taken into account. Second, one might see whether the results can 
be replicated with data from other countries, such as Canada, in which different levels of government also share the same tax bases.

Our findings have some potentially interesting normative implications. If the revenue effect induces a positive interdependence between federal and state tax rates, then federal systems are potentially susceptible to a "tragedy of the commons" in which non-cooperative tax setting between federal and state governments results in excessive taxation of common tax bases. This kind of vertical externality in a federal structure has received less prominent discussion than horizontal externalities due to the mobility of tax bases among jurisdictions. Our results suggest that vertical externalities can, however, be an important consideration for evolving federations that are seeking to design tax constitutions which divide responsibility among tiers of government. 


\section{References}

[1] Besley, Timothy and Anne Case, "Does Electoral Accountability Affect Economic Policy Choices? Evidence from Gubernatorial Term Limits," Quarterly Joumal of Economics, volume CX, no. 3, August 1995, pp. 769-798.

[2] Boadway, Robin and Michael Keen, "Efficiency and the Fiscal Gap in Federal Systems," mimeo, Queens University, 1994.

[3] Craig, Steven G. and Robert P. Inman, "Education, Welfare, and the 'New' Federalism: State Budgeting in a Federalist Public Economy," in Harvey S. Rosen (ed.), Studies in State and Local Public Finance, Chicago: University of Chicago Press, 1986, pp. 187-222.

[4] Dahlby, Bev, "Distortionary Taxation and the Design of Intergovernmental Grants," mimeo, University of Alberta, 1995.

[5] Dixit, Avinash, "Special-Interest Lobbying and Endogenous Commodity Taxation," Eastern Economic Journal, 22, no. 4, Fall 1996, pp. 375-388.

[6] Feenberg, Daniel R., Andrew W. Mitrusi, and James M. Poterba, "Distributional Effects of Adopting a National Retail Sales Tax," National Bureau of Economic Research, Working Paper No. 5885, January 1997.

[7] Fullerton, Don and Diane Lim Rogers, Who Bears the Lifetime Tax Burden? Washington, DC: Brookings Institution, 1993.

[8] Hamermesh, Daniel, and David Scoones, "Multilevel 'General Policy Equilibria': Evidence from the American Unemployment Insurance Tax Ceiling," National Bureau of Economic Research, Working Paper No. 5578, May 1996.

[9] Hettich, Walter and Stanley Winer, "Economic and Political Foundations of Tax Structure," American Economic Review 78, no. 4, September 1988, pp. 701-712.

[10] Hines, James R. Jr., and Richard H. Thaler, "The Flypaper Effect," Journal of Economic Perspectives, 9, no. 4, Fall 1995, pp. 217-226. 
[11] Holtz-Eakin, Douglas, "The Line Item Veto and Public Sector Budgets: Evidence from the States," Journal of Public Economics 36, 1988, pp. 269292.

[12] Moulton, Brent R., "Random Group Effects and the Precision of Regression Estimates," Journal of Econometrics 32, August 1986, pp. 385-397.

[13] Oates, Wallace, E. and Robert M. Schwab, "Economic Competition Among Jurisdictions: Efficiency-Enhancing or Distortion-Inducing," Journal of Public Economics, April 1988, pp.333-54.

[14] U.S. Bureau of Census, Statistical Abstract of the United States (111th edition), U.S. Government Printing Office, Washington D.C., 1991.

[15] U.S. Congress, Joint Committee on Taxation, Impact on State and Local Governments and Tax-exempt Organizations of Replacing the Federal Income Tax, U.S. Government Printing Office, Washington, DC 1996.

[16] White, Halbert, "A Heteroskedasticity-Consistent Covariance Matrix Estimator and a Direct Test for Heteroskedasticity," Econometrica 48, 1980, pp. $817-838$. 
Table 1

Summary Statistics ${ }^{1}$

\begin{tabular}{|c|c|}
\hline Variable & \\
\hline$t_{C}$ (state unit cigarette tax, 1983 cents) & $\begin{array}{l}17.09 \\
(6.83)\end{array}$ \\
\hline$t_{G}$ (state unit gasoline tax, 1983 cents & $\begin{array}{l}11.97 \\
(2.71)\end{array}$ \\
\hline $\begin{array}{l}\hat{\mathrm{t}}_{\mathrm{C}} \text { (state unit cigarette tax, inclusive of } \\
\text { general sales } \operatorname{tax}, 1983 \text { cents }\end{array}$ & $\begin{array}{l}19.54 \\
(7.34) \\
\end{array}$ \\
\hline $\begin{array}{l}\hat{\mathrm{t}}_{\mathrm{G}} \text { (state unit gasoline tax, inclusive of } \\
\text { general sales } \operatorname{tax}, 1983 \text { cents) }\end{array}$ & $\begin{array}{l}12.51 \\
(2.94) \\
\end{array}$ \\
\hline$t_{\text {gen }}$ (state general tax rate, percent) & $\begin{array}{l}3.83 \\
(1.66)\end{array}$ \\
\hline $\mathrm{T}_{\mathrm{C}}$ (federal unit cigarette tax, 1983 cents) & $\begin{array}{l}12.91 \\
(2.34)\end{array}$ \\
\hline $\mathrm{T}_{\mathrm{G}}$ (federal unit gasoline tax, 1983 cents) & $\begin{array}{l}6.808 \\
(1.43)\end{array}$ \\
\hline $\begin{array}{l}\text { GDP (real national gross domestic product, } \\
\text { billions of } 1983 \text { dollars) }\end{array}$ & $\begin{array}{l}3,062 \\
(357)\end{array}$ \\
\hline $\mathrm{U}_{\text {fed }}$ (unemployment rate) & $\begin{array}{l}7.08 \\
(1.26)\end{array}$ \\
\hline POP (state population) & $\begin{array}{l}4,759,000 \\
(4,869,000)\end{array}$ \\
\hline INC (state income per capita in 1983 dollars) & $\begin{array}{l}11,600 \\
(1,868)\end{array}$ \\
\hline $\mathrm{U}_{\text {State }}$ (state unemployment rate) & $\begin{array}{l}6.894 \\
(2.290)\end{array}$ \\
\hline $\begin{array}{l}\text { CHILD (proportion of population between } \\
5 \text { and } 17 \text { ) }\end{array}$ & $\begin{array}{l}0.2078 \\
(0.02314)\end{array}$ \\
\hline AGED (proportion of population over 65) & $\begin{array}{l}0.1156 \\
(0.01873)\end{array}$ \\
\hline $\begin{array}{l}\text { TOBINC(tobacco production per dollar of } \\
\text { state income) }\end{array}$ & $\begin{array}{l}0.01257 \\
(0.03815)\end{array}$ \\
\hline $\begin{array}{l}\text { GASINC(daily gasoline production per dollar } \\
\text { of state income) }\end{array}$ & $\begin{array}{l}0.003447 \\
(0.01186)\end{array}$ \\
\hline $\begin{array}{l}\text { GRANTS (federal grants per capita in } 1983 \\
\text { dollars) }\end{array}$ & $\begin{array}{l}463.3 \\
(124)\end{array}$ \\
\hline $\begin{array}{l}\mathrm{T}_{\text {inc }} \text { (federal income tax divided by adjusted } \\
\text { gross income) }\end{array}$ & $\begin{array}{l}13.83 \\
(1.574)\end{array}$ \\
\hline
\end{tabular}


Table 1 (continued)

\begin{tabular}{|l|l|}
\hline Variable & \\
\hline DEMGOV ( $=1$ if the governor is a Democrat) & 0.6347 \\
& $(0.4818)$ \\
\hline DEMSEN (proportion of state Senate that is & 0.6302 \\
Democratic) & $(0.1976)$ \\
\hline DEMHOU (proportion of state House that is & 0.6193 \\
Democratic) & $(0.1885)$ \\
\hline DEF (federal deficit/GDP) & 3.63 \\
& $(1.21)$ \\
\hline
\end{tabular}

${ }^{1}$ Figures are means, with standard deviations in parentheses, based on annual data for the continental states for the years 1975 to 1989 , inclusive.

Sources: State tax rates on tobacco are from various editions of The Tax Burden on Tobacco published by the Tobacco Institute. State tax rates on gasoline are from various editions of Highway Statistics, published by the Federal Highway Administration and from various editions of the State Energy and Price Report, published by the Energy Information Administration. Federal tax rates on gasoline and tobacco are from Federal Taxation of Tobacco, Alcoholic Beverages and Motor Fuels, Office of Management and Budget (August 1990). Federal income tax rates are from Statistics of Income-Individual Income Tax Returns. State general sales tax rates, real GDP, national unemployment rates, state population, state income, and proportions of children and the aged are from various editions of Statistical Abstract of the United States. Tobacco production is from various editions of Annual Report on Tobacco Statistics by the U.S. Department of Agriculture. Gasoline production is from Petroleum Supply Annual and Energy Data Reports, Petroleum Statement Annual, by the Energy Information Administration (1983). Information on political parties of the governor and the legislature are from various editions of Book of the States by the Council of State Governments (Lexington, Kentucky). Federal deficit figures are from The Economic and Budget Outlook: Fiscal Years 1997-2006 by the Congressional Budget Office. 
Table 2

Parameter Estimates ${ }^{2}$

\begin{tabular}{|c|c|c|c|c|c|}
\hline Variable & $\begin{array}{l}(1) \\
t_{C} \\
\end{array}$ & $\begin{array}{r}(2) \\
t_{G} \\
\end{array}$ & $\begin{array}{r}(3) \\
\hat{\mathrm{t}}_{\mathrm{C}} \\
\end{array}$ & $\begin{array}{l}(4) \\
\hat{t}_{G} \\
\end{array}$ & $\begin{array}{l}(5) \\
t_{\text {gen }}\end{array}$ \\
\hline $\mathrm{T}_{\mathrm{C}}$ & $\begin{array}{l}0.2766 \\
(0.1021) \\
\end{array}$ & - & $\begin{array}{l}0.3414 \\
(0.1205) \\
\end{array}$ & & $\begin{array}{l}0.02585 \\
(0.00637) \\
\end{array}$ \\
\hline $\mathrm{T}_{\mathrm{G}}$ & - & $\begin{array}{l}0.4126 \\
(0.1514)\end{array}$ & - & $\begin{array}{l}0.3783 \\
(0.1384)\end{array}$ & - \\
\hline GDP & $\begin{array}{l}0.003935 \\
(0.001584)\end{array}$ & $\begin{array}{l}-0.0001346 \\
(0.001365)\end{array}$ & $\begin{array}{l}0.006630 \\
(0.001800)\end{array}$ & $\begin{array}{r}-.0009609 \\
(0.001230)\end{array}$ & $\begin{array}{l}0.001409 \\
(.0001813)\end{array}$ \\
\hline $\mathrm{U}_{\mathrm{fed}}$ & $\begin{array}{l}-0.2069 \\
(0.3002) \\
\end{array}$ & $\begin{array}{r}-0.2807 \\
(0.2149) \\
\end{array}$ & $\begin{array}{l}-0.06021 \\
(0.3499)\end{array}$ & $\begin{array}{l}-0.3695 \\
(0.1888) \\
\end{array}$ & $\begin{array}{l}0.1048 \\
(0.02398) \\
\end{array}$ \\
\hline $\begin{array}{l}\text { POP } \\
\left(\times 10^{-6}\right)\end{array}$ & $\begin{array}{l}-2.60 \\
(0.995)\end{array}$ & $\begin{array}{l}0.692 \\
(0.269)\end{array}$ & $\begin{array}{l}-2.08 \\
(0.912)\end{array}$ & $\begin{array}{l}0.217 \\
(0.365)\end{array}$ & $\begin{array}{l}0.441 \\
(0.0967)\end{array}$ \\
\hline $\begin{array}{l}\mathrm{POP}^{2} \\
\left(\times 10^{-12}\right)\end{array}$ & $\begin{array}{l}0.0509 \\
(0.0332)\end{array}$ & $\begin{array}{c}-0.00685 \\
(0.00623)\end{array}$ & $\begin{array}{c}-0.0393 \\
(0.0318)\end{array}$ & $\begin{array}{r}-0.00711 \\
(0.00929)\end{array}$ & $\begin{array}{l}-0.0109 \\
(0.00176)\end{array}$ \\
\hline INC & $\begin{array}{c}-0.001155 \\
(0.001026)\end{array}$ & $\begin{array}{c}-0.0002038 \\
(0.0005179)\end{array}$ & $\begin{array}{c}-.0009621 \\
(0.001207)\end{array}$ & $\begin{array}{c}-.0002906 \\
(.0005249)\end{array}$ & $\begin{array}{l}-0.0002207 \\
(0.0000736)\end{array}$ \\
\hline $\begin{array}{l}\mathrm{INC}^{2} \\
\left(\times 10^{-6}\right)\end{array}$ & $\begin{array}{l}0.0448 \\
(0.0338)\end{array}$ & $\begin{array}{l}0.00829 \\
(0.0164)\end{array}$ & $\begin{array}{l}0.0404 \\
(0.0402) \\
\end{array}$ & $\begin{array}{l}0.0115 \\
(0.0164)\end{array}$ & $\begin{array}{l}0.00506 \\
(0.00251)\end{array}$ \\
\hline $\mathrm{U}_{\text {State }}$ & $\begin{array}{l}0.07388 \\
(0.09101)\end{array}$ & $\begin{array}{l}0.1479 \\
(0.06096)\end{array}$ & $\begin{array}{l}0.05598 \\
(0.09402) \\
\end{array}$ & $\begin{array}{l}0.2181 \\
(0.05611)\end{array}$ & $\begin{array}{l}-0.02111 \\
(0.008573)\end{array}$ \\
\hline CHILD & $\begin{array}{l}150.9 \\
(18.67)\end{array}$ & $\begin{array}{l}63.33 \\
(17.42) \\
\end{array}$ & $\begin{array}{l}168.4 \\
(20.33) \\
\end{array}$ & $\begin{array}{l}56.96 \\
(16.92) \\
\end{array}$ & $\begin{array}{l}6.302 \\
(2.344) \\
\end{array}$ \\
\hline AGED & $\begin{array}{l}-76.91 \\
(29.48)\end{array}$ & $\begin{array}{l}43.89 \\
(16.27)\end{array}$ & $\begin{array}{l}-94.01 \\
(35.26)\end{array}$ & $\begin{array}{l}59.04 \\
(20.64)\end{array}$ & $\begin{array}{l}.8953 \\
(2.270)\end{array}$ \\
\hline TOBINC & $\begin{array}{l}-55.59 \\
(33.29)\end{array}$ & $\begin{array}{l}8.546 \\
(16.13) \\
\end{array}$ & $\begin{array}{l}-40.36 \\
(34.33)\end{array}$ & $\begin{array}{l}6.421 \\
(17.00)\end{array}$ & $\begin{array}{l}14.54 \\
(1.967) \\
\end{array}$ \\
\hline GASINC & $\begin{array}{l}23.04 \\
(9.693)\end{array}$ & $\begin{array}{l}-25.15 \\
(4.215)\end{array}$ & $\begin{array}{l}8.753 \\
(12.48)\end{array}$ & $\begin{array}{l}-22.99 \\
(4.086)\end{array}$ & $\begin{array}{l}-1.471 \\
(.9963)\end{array}$ \\
\hline GRANTS & $\begin{array}{l}-0.006535 \\
(0.004216)\end{array}$ & $\begin{array}{l}-0.002219 \\
(0.003124)\end{array}$ & $\begin{array}{l}-.006468 \\
(0.004745)\end{array}$ & $\begin{array}{c}-0.001784 \\
(0.002991)\end{array}$ & $\begin{array}{l}0.0004127 \\
(.0002865)\end{array}$ \\
\hline $\mathrm{T}_{\text {INC }}$ & $\begin{array}{l}-0.1904 \\
(0.1344)\end{array}$ & $\begin{array}{l}-0.1860 \\
(0.1489)\end{array}$ & $\begin{array}{l}-0.2157 \\
(0.1696)\end{array}$ & $\begin{array}{l}-0.1641 \\
(0.1334) \\
\end{array}$ & $\begin{array}{c}-0.006978 \\
(0.007136)\end{array}$ \\
\hline
\end{tabular}


Table 2:

Parameter Estimates - (Continued)

\begin{tabular}{|c|c|c|c|c|c|}
\hline Variable & $\begin{array}{r}(1) \\
t_{C}\end{array}$ & $\begin{array}{l}(2) \\
t_{G}\end{array}$ & $\begin{array}{l}(3) \\
\hat{t}_{C} \\
\end{array}$ & $\begin{array}{r}(4) \\
\hat{t}_{G} \\
\end{array}$ & $\begin{array}{l}(5) \\
t_{\text {genl }}\end{array}$ \\
\hline DEMGOV & $\begin{array}{l}0.5510 \\
(0.1208)\end{array}$ & $\begin{array}{l}0.3150 \\
(0.1714)\end{array}$ & $\begin{array}{l}0.7208 \\
(0.1500)\end{array}$ & $\begin{array}{l}0.2659 \\
(0.1745)\end{array}$ & $\begin{array}{l}-.001769 \\
(.01960)\end{array}$ \\
\hline DEMSEN & $\begin{array}{l}-2.155 \\
(1.243)\end{array}$ & $\begin{array}{l}-1.712 \\
(0.5336)\end{array}$ & $\begin{array}{l}0.5854 \\
(1.572)\end{array}$ & $\begin{array}{c}-1.378 \\
(0.5989)\end{array}$ & $\begin{array}{l}0.6959 \\
(0.2315) \\
\end{array}$ \\
\hline DEMHOU & $\begin{array}{l}5.602 \\
(2.820) \\
\end{array}$ & $\begin{array}{l}0.9007 \\
(1.659) \\
\end{array}$ & $\begin{array}{l}5.392 \\
(3.352) \\
\end{array}$ & $\begin{array}{l}.5967 \\
(1.498) \\
\end{array}$ & $\begin{array}{l}0.1196 \\
(0.2392) \\
\end{array}$ \\
\hline CONSTANT & $\begin{array}{l}-3.906 \\
(14.58)\end{array}$ & $\begin{array}{l}-2.073 \\
(11.56)\end{array}$ & $\begin{array}{l}-17.61 \\
(17.16)\end{array}$ & $\begin{array}{l}-1.281 \\
(11.77)\end{array}$ & $\begin{array}{l}-3.417 \\
(1.378) \\
\end{array}$ \\
\hline $\mathrm{N}$ & 705 & 705 & 705 & 705 & 705 \\
\hline
\end{tabular}

${ }^{2}$ These are least squares estinates of the parameters in Equation (2.1). Numbers in parentheses are robust standard errors. Variables are defined in Table 1. Each equation in the table is estimated with state effects. 
Table 3

Instrumental Variables Estimates ${ }^{3}$

\begin{tabular}{|c|c|c|c|c|c|}
\hline Variable & $\begin{array}{r}(1) \\
t_{C} \\
\end{array}$ & $\begin{array}{r}(2) \\
t_{G} \\
\end{array}$ & $\begin{array}{l}(3) \\
\hat{\mathbf{t}}_{\mathrm{C}} \\
\end{array}$ & $\begin{array}{l}(4) \\
\hat{t}_{G} \\
\end{array}$ & $\begin{array}{l}5) \\
t_{\text {gen }} \\
\end{array}$ \\
\hline $\mathrm{T}_{\mathrm{C}}$ & $\begin{array}{l}0.2742 \\
(0.1089) \\
\end{array}$ & - & $\begin{array}{l}0.3341 \\
(0.1228) \\
\end{array}$ & - & $\begin{array}{l}0.0206 \\
(0.00521)\end{array}$ \\
\hline $\mathrm{T}_{\mathrm{G}}$ & - & $\begin{array}{l}0.3197 \\
(0.1304) \\
\end{array}$ & - & $\begin{array}{l}0.2823 \\
(0.1182) \\
\end{array}$ & - \\
\hline GDP & $\begin{array}{l}0.003954 \\
(0.001588) \\
\end{array}$ & $\begin{array}{l}0.0003444 \\
(0.001216) \\
\end{array}$ & $\begin{array}{l}0.006688 \\
(0.001788) \\
\end{array}$ & $\begin{array}{l}-0.0004662 \\
(0.001072)\end{array}$ & $\begin{array}{l}0.001451 \\
(0.0001839) \\
\end{array}$ \\
\hline $\mathrm{U}_{\text {fed }}$ & $\begin{array}{l}-0.2033 \\
(0.2952) \\
\end{array}$ & $\begin{array}{l}-0.2099 \\
(0.1847) \\
\end{array}$ & $\begin{array}{l}-0.04889 \\
(0.3439)\end{array}$ & $\begin{array}{l}-0.2964 \\
(0.1588) \\
\end{array}$ & $\begin{array}{l}0.1129 \\
(0.02421) \\
\end{array}$ \\
\hline $\begin{array}{l}\text { POP } \\
\left(\times 10^{-6}\right)\end{array}$ & $\begin{array}{l}-2.60 \\
(0.0996) \\
\end{array}$ & $\begin{array}{l}-0.702 \\
(0.274) \\
\end{array}$ & $\begin{array}{l}-2.08 \\
(0.914)\end{array}$ & $\begin{array}{l}-0.227 \\
(0.369) \\
\end{array}$ & $\begin{array}{l}0.440 \\
(0.0969) \\
\end{array}$ \\
\hline $\begin{array}{l}\mathrm{POP}^{2} \\
\left(\times 10^{-12}\right)\end{array}$ & $\begin{array}{l}0.0509 \\
(0.0332) \\
\end{array}$ & $\begin{array}{l}0.00717 \\
(0.00630) \\
\end{array}$ & $\begin{array}{l}-0.0393 \\
(0.0318) \\
\end{array}$ & $\begin{array}{l}-0.00697 \\
(0.00934) \\
\end{array}$ & $\begin{array}{l}-0.0109 \\
(0.00177) \\
\end{array}$ \\
\hline INC & $\begin{array}{l}-0.001150 \\
(0.000995)\end{array}$ & $\begin{array}{r}-0.0000735 \\
(0.0005149)\end{array}$ & $\begin{array}{r}-.0009443 \\
(0.001172)\end{array}$ & $\begin{array}{l}-0.000156 \\
(0.0005341)\end{array}$ & $\begin{array}{l}-0.0002079 \\
(0.0000688) \\
\end{array}$ \\
\hline $\begin{array}{l}\text { INC }^{2} \\
\left(\times 10^{-6}\right)\end{array}$ & $\begin{array}{l}0.0447 \\
(0.0372)\end{array}$ & $\begin{array}{l}0.00528 \\
(0.0169) \\
\end{array}$ & $\begin{array}{l}0.0400 \\
(0.0395)\end{array}$ & $\begin{array}{l}0.00844 \\
(0.0171) \\
\end{array}$ & $\begin{array}{l}0.00478 \\
(0.00240) \\
\end{array}$ \\
\hline $\mathrm{U}_{\text {State }}$ & $\begin{array}{l}0.07399 \\
(0.0906) \\
\end{array}$ & $\begin{array}{l}0.1515 \\
(0.06172) \\
\end{array}$ & $\begin{array}{l}0.05632 \\
(0.09342) \\
\end{array}$ & $\begin{array}{l}0.2218 \\
(0.05699) \\
\end{array}$ & $\begin{array}{l}-0.02086 \\
(0.008493) \\
\end{array}$ \\
\hline CHILD & $\begin{array}{l}151.2 \\
(18.52) \\
\end{array}$ & $\begin{array}{l}67.80 \\
(15.64) \\
\end{array}$ & $\begin{array}{l}169.1 \\
(20.14) \\
\end{array}$ & $\begin{array}{l}61.58 \\
(15.11)\end{array}$ & $\begin{array}{l}6.784 \\
(2.508) \\
\end{array}$ \\
\hline AGED & $\begin{array}{l}-76.94 \\
(29.53) \\
\end{array}$ & $\begin{array}{l}42.76 \\
(16.87) \\
\end{array}$ & $\begin{array}{r}-94.11 \\
(35.23) \\
\end{array}$ & $\begin{array}{l}57.88 \\
(21.51) \\
\end{array}$ & $\begin{array}{l}.8216 \\
(2.252) \\
\end{array}$ \\
\hline TOBINC & $\begin{array}{l}-55.67 \\
(33.76) \\
\end{array}$ & $\begin{array}{l}7.077 \\
(16.50) \\
\end{array}$ & $\begin{array}{l}-40.61 \\
(34.85) \\
\end{array}$ & $\begin{array}{l}.903 \\
(17.39) \\
\end{array}$ & $\begin{array}{l}14.36 \\
(2.010) \\
\end{array}$ \\
\hline GASINC & $\begin{array}{l}23.05 \\
(9.673) \\
\end{array}$ & $\begin{array}{r}-24.77 \\
(4.442) \\
\end{array}$ & $\begin{array}{l}8.783 \\
(12.48) \\
\end{array}$ & $\begin{array}{l}-22.60 \\
(4.341) \\
\end{array}$ & $\begin{array}{l}-1.449 \\
(1.025) \\
\end{array}$ \\
\hline GRANTS & $\begin{array}{l}-0.006518 \\
(0.004075)\end{array}$ & $\begin{array}{l}-0.001879 \\
(0.003217) \\
\end{array}$ & $\begin{array}{l}-0.006416 \\
(0.004577)\end{array}$ & $\begin{array}{l}-0.001432 \\
(0.003106)\end{array}$ & $\begin{array}{l}0.0004495 \\
(0.0002967) \\
\end{array}$ \\
\hline $\mathrm{T}_{\mathrm{INC}}$ & $\begin{array}{c}-0.1914 \\
(0.1401) \\
\end{array}$ & $\begin{array}{l}-0.2075 \\
(0.1683)\end{array}$ & $\begin{array}{l}-0.2189 \\
(0.1772)\end{array}$ & $\begin{array}{l}-0.1863 \\
(0.1538)\end{array}$ & $\begin{array}{l}-0.009305 \\
(0.008118)\end{array}$ \\
\hline
\end{tabular}


Table 3 Instrumental Variables Estimates - (Continued)

\begin{tabular}{|l|l|l|l|l|l|}
\hline Variable & $\begin{array}{c}(1) \\
\mathrm{t}_{\mathrm{C}}\end{array}$ & $\begin{array}{c}(2) \\
\mathrm{t}_{\mathrm{G}}\end{array}$ & $\begin{array}{c}(3) \\
\hat{\mathrm{t}}_{\mathrm{C}}\end{array}$ & $\begin{array}{c}(4) \\
\hat{\mathrm{t}}_{\mathrm{G}}\end{array}$ & $\begin{array}{c}(5) \\
\mathrm{t}_{\mathrm{gc1}}\end{array}$ \\
\hline \multirow{2}{*}{ DEMGOV } & 0.5522 & 0.3432 & 0.7247 & 0.2951 & -.000978 \\
& $(0.1201)$ & $(0.1780)$ & $(0.1498)$ & $(0.1814)$ & $(0.01975)$ \\
\hline \multirow{2}{*}{ DEMSEN } & -2.157 & -1.758 & 0.5803 & -1.424 & 0.6922 \\
& $(1.242)$ & $(0.5326)$ & $(1.565)$ & $(0.5986)$ & $(0.2295)$ \\
\hline \multirow{2}{*}{ DEMHOU } & 5.616 & 1.178 & 5.436 & 0.8835 & 0.1512 \\
& $(2.857)$ & $(1.637)$ & $(3.375)$ & $(1.473)$ & $(0.2327)$ \\
\hline \multirow{2}{*}{ CONSTANT } & -4.050 & -5.325 & -18.06 & -4.640 & -3.739 \\
& $(13.77)$ & $(10.46)$ & $(16.31)$ & $(10.78)$ & $(1.362)$ \\
\hline $\mathrm{N}$ & 705 & 705 & 705 & 705 & 705 \\
\hline
\end{tabular}

${ }^{3}$ These are instrumental variables estimates of the parameters in Equation (2.1). The variables $T_{C}$ and $T_{G}$ are treated as endogenous, and the instrument is DEF. Variables are defined in Table 1. Each equation in the table is estimated with state effects. 